\title{
The Practice of Bilingualism in Andalusia, Spain
}

\author{
$\mathrm{M}^{\mathrm{a}}$ del Carmen Ruiz Pérez \\ Junta de Andalucía, Spain
}

\begin{abstract}
A bilingual education program consists of teaching a substantial part of a subject in a different language from the native language of the students. These programs exist in several countries around the world, for example USA, Niger, Mozambique, India or Spain. It is wide accepted the positive effects of knowing a second language, not only in economic aspects (efficiency and cost saving of being able to communicate without traslator, for example), but also improving memory, enhancing concentration, etc.

An investment by the state in bilingual education is an investment in the long term future of the workforce, known as human capital. This investment returns to the individual (higher earning), and also to the economy as a whole (higher productivity).

The objective of this study is to analyze the implementation of the Bilingual Project in a Secundary School in the South of Spain. The pupils study English as a second language and French as a third language. Furthemore, some other subjects, such as Social Science, Biology and Technology must be taught in English, at least, the 50\% of the classes. This is what the legal system says, but what is the reality?.
\end{abstract}

\section{Introduction}

The Spanish Educational System is composed of 3 years of pre-school, from ages 3 to 5, 6 years of Primary School, 4 years of compulsory Secundary Education (E.S.O.) and 2 years of non-compulsary education, which is divided into preparation for College (Bachillerato) and vocational training (Ciclos Formativos).

My school is located in a working-class neighborhood, in the South of Spain. It's a small secondary school, with near 400 students, whose ages are between twelve and sixteen years old. It's a bilingual school, but not all students are bilinguals. For example, we have four groups in the second year, but only two of them are bilinguals. Some people could think that all subjects are teaching in English, but the reality is that only 2 or 3 subjects (depends on the course) are bilinguals: Social Science, Biology and Technology (there are 11 subjects in a course).

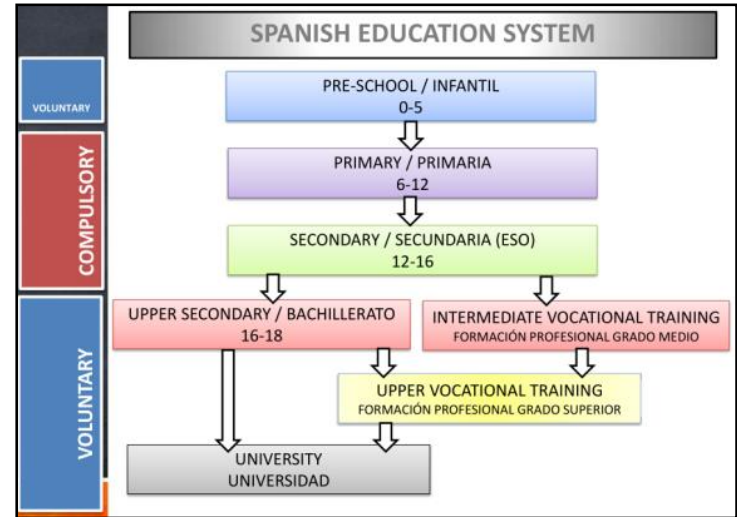

Figure 1. Spanish Education System

\section{The Bilingualism in Andalusia}

The bilingual education has been implemented in many countries for several years now, and it continues catching "the attention of policy-maker, schools, parents, students, national and regional authorities, international bodies such as the European Comission and the Council of Europe, and the wider public (including the media)" [1, p. 11].

The "adventure" of the Bilinguism in Andalusia started en 2005. This year the Andalusia Goverment aproved a Plan or a Program to encorage the learning of foreign languages, in order to improve the comunicative competence ("Plurilingualism Promotion Plan" or Plan de Fomento del Plurilingüismo) [2]. The following year, 101 state schools started the English bilingual program. Nowadays, in the school year 2018-2019, there are 1417 bilingual centres and 460,975 students. There has been an increase by around 100 new bilingual centres each year during this period (12 years). The new Strategic Plan for the Development of Languages in Andalusia "Horizon 2020" [3] seeks to give continuity to the previous strategic plan and to further develop bilingual education in this autonomous community [4]. Although, analyzing just these datas we can think the Andalusia Government has done a huge effort to encorage the bilinguism, this effort has not been enough: sometimes, politicians only want to show off about numbers ("we have many bilingual schools"), but they don't invest enough in resorces for the school, 
giving more support and better qualification and training to their teachers or having teachers of both nationalities, for example. Some education experts defend the idea of it is preferable to improve existing organisational structures rather than create new centres [5].

\section{My School}

The bilingualism is very important in my school, it's really engaged with the project. Since 2007 we have been preparing units and activities to use in our classes. At the same time, teachers have been studying English at the Official Language Schools, Teacher Training Centres or participating in summer immersion programs (during their holidays) to improve their level in this foreign language. It has been a hard work, many hours of our free time searching, reading, selecting and writing activities. This shows a clear commitment on the part of the teachers. It's crucial for pupils to have accurate models of language to ensure that language is correctly produced, that is why it's very important to participate in courses in Spain and abroad. The significant extra personal time investment made by many bilingual teacher is given willingly and refects a vocation. Teachers must pay for their own specific training. However, the Administration shows a lack of value or recognition, economically and morally, towards the efforts done by teachers [5].

The use of technology in bilingual education plays an esencial role in the development of materials for bilingual education (i.e. slides, videos, games, websites, etc). Bilingual teachers should develop their digital competence, essential for designing didactic units or classroom activities [6], for example. After twelve years we have a huge bank of bilingual activities, but what it's more important, we have a common bilingual curriculum.

Table 1. Common bilingual curriculum in the first year

\begin{tabular}{|c|c|c|c|}
\hline Language & $\begin{array}{c}\text { UNIT 1 } \\
\text { (first term) }\end{array}$ & $\begin{array}{c}\text { UNIT 2 } \\
\text { (2nd term) }\end{array}$ & $\begin{array}{c}\text { UNIT 3 } \\
\text { (3rd term) }\end{array}$ \\
\hline The school & $\begin{array}{c}\text { The body /health } \\
\text { Weather } \\
\text { The house }\end{array}$ & $\begin{array}{c}\text { Languages in } \\
\text { the world } \\
\text { Sms }\end{array}$ \\
\hline $\begin{array}{c}\text { Social } \\
\text { Science }\end{array}$ & Maps/scales & $\begin{array}{c}\text { Weather and } \\
\text { climate }\end{array}$ & $\begin{array}{c}\text { Legacy of } \\
\text { Rome }\end{array}$ \\
\hline Biology & The Earth & Living beings & $\begin{array}{c}\text { Plants } \\
\text { Ecosystem }\end{array}$ \\
\hline
\end{tabular}

We have also elaborated the PLC (Linguistic Project Centre), a common curriculum of languages that involve the centre as a whole and not only the bilingual team.

\section{Methodology}

Bilingual education is based on the CLIL (Content and Language Integrated Learning) aproach. This methodology consists in the study of some of the subjects of the curriculm through the use of a foreign or a second language [7] [8] [9]. This practice "promotes a more natural use of language, where learners learn and use languages for different purposes and in various contexts, which leads to attention and tolerance towards other cultures" [1, p. 173], and it also promotes collaborative work between students. This methodology has been used in around 20 countries across Europe from the beginning of the 1990s mainly in Primary and Secundary Education.

CLIL methodology promotes key competence development, particularly the key competences of multilingual and multicultural citizenship. The important growth of bilingual education in public schools in Spain has been seen as an opportunity for real development of communicative competence among learners. However, there are arguments for and against this program, not only in educational circles, but also in the press (media) [10].

The Non Linguistic Subjects that are engaged with this bilingual program in my school are Biology, Technology and Social Science. At leat the $50 \%$ of each subject must be taught in English. This year we have a native speaker assistant, who comes one hour a week to our classes.

This program involve cross-disciplinary activities, with the same final project for all subjets (a video, a power point presentation, a poster, etc.).

\section{Status of the issue}

It is widely recognised the benefits of a bilingual education, we are not going to discuss this aspect. But, if we want a good bilingual education, a high quality education, there are some points we have to improve:

- There are many students per class, between 30 and 34 pupils.

- Bilingual education increases the difficulty of learning academic content due to it being taught in a non-native language. Some researches [11] [12] show a small, but significant, negative impact of the program in this facet.

- There are bilingual and not bilingual students in the same class. So, you can't teach properly a lesson, because you have to prepare different activities for each group.

- But the most complicate issue is the attention to the Special Needs and different levels of English in the same class. There are some students that have a very good level of 
English and are hardworkers, but there are many others that hardly know basic words in English, even in their mother tongue have low level of specific vocabulary, and they don't have any interest in studying.

- Teachers have to teach many groups, bilingual and no bilingual, in different courses, so they must prepare many different lessons and activities. Furthermore, they are not English native speakers, they have studied the language after finishing their degrees, even some of them, working and studying at the same time. This means, that they don't have an "excellent" level of English, but they are engaged with the project, and they are trying in any occasion to improve their level, at languages school, in immersion summer courses, reading, etc. In my school, most of bilingual teachers have the $\mathrm{C} 1$ level of English.

- The school should be provided with one native language assistant, but sometimes we have either to share the language assistant with another school or don't have any. Although these assistants do not generally have formal teaching qualification, they "can provide high quality linguistic and cultural imput" [10, p. 122] and bring high levels of enthusiasm to the class.

However, there are also many positive impacts of the bilingual program in my school:

- First of all, a positive bilingual environment. There are posters, photos of bilingual projects and activities inside the schools, on internet and in social network (twitter and instragram).

- The coordinator participates and encourages participation in projects inside and outside the school (Erasmus+, bilingual partnership).

- My school is awared of the importance of creating working partnership between content and language teachers.

- There is effective cordination between language and non-language teacher in terms of planning and evaluation.

- Language and non-language teachers participate in international projects (Erasmus+ KA1, staff mobility in Finland and Slovenia).

There is a research in Andalusia about learners opinions with respect to bilinguism [13]. The study shows students are satisfied with this program and they are aware of the importance of studying a foreign language, not only for cognitive benefits, but also in order to get a better job position in the future. Most of our former students are finished their university studies with very good marks and very good level of English too.

\section{References}

[1] Gómez Parra, M.E. and Johnstone, R., coords., Educación Bilingüe: Tendencias educativas y conceptos claves. Bilingual Education: Educational trends and key concepts, Ministerio de Educación, Cultura y Deporte. 2017.

[2] Plan de Fomento del Plurilingüismo en Andalucía, Boletín Oficial de la Junta de Andalucía, Boletín número 65 de 05/04/2005.

[3] Plan estrategico de Desarrollo de las Lenguas en Andalucía. Horizonte 2020, Consejería de Educación, Junta de Andalucía, 2017.

[4] Martínez Serrano, L.M. "In-Service Teacher Professional Development and Bilingual Education: Towards a Comprehensive Teacher Training Curriculum, Gómez Parra, M.E. and Johnstone, R., coords., Educación Bilingüe: Tendencias educativas y conceptos claves. Bilingual Education: Educational trends and key concepts, Ministerio de Educación, Cultura y Deporte, 2017, pp. 197-208.

[5] Díaz López, M.R. Análisis de la implantación del bilingüismo en centros educativos públicos, en contextos rurales de la provincia de Málaga, desde un enfoque de educación inclusiva, Tesis doctoral, Universidad de Málaga, 2017.

[6] Huertas Abril, C., "The Role of Technology in the Development of Materials for Bilingual Education", in Gómez Parra, M.E. and Johnstone, R., coords., Educación Bilingüe: Tendencias educativas y conceptos claves. Bilingual Education: Educational trends and key concepts. Ministerio de Educación, Cultura y Deporte, 2017, pp. 209-220.

[7] Pérez Crespo, M. M., CLIL in Andalusia: Study on teachers' view. Trabajo Fin de Grado, Universidad de Jaén. 2015.

[8] Dobson, A., Pérez Murillo, M.D. y Johnstone, R., Independent evaluation of the Bilingual Education Project of the Ministry of Education (Spain) and the British Council (Spain), Online supplement, British Council, Ministerio de Educación, 2011.

[9] Almenta López, E., La formación inicial del profesorado de Secundaria de la rama de Educación Bilingüe-CLIL. Un estudio de caso en la Universidad de Utrecht (Holanda), Universidad de Málaga, Tesis doctoral, 2015. 
[10] Ortega Martín, J.L. and Hugues, S.P. "Key Issues in the Management of Bilingual Education", en Gómez Parra, M.E. and Johnstone, R., coords (2017) Educación Bilingüe: Tendencias educativas y conceptos claves. Bilingual Education: Educational trends and key concepts. Ministerio de Educación, Cultura y Deporte, p. 117-127.

[11] Ruiz, M. Bilingual Education: experience from Madrid. Master Thesis CEMFI, Madrid, 2017. 